\title{
東京医科歯科大学歯学部附属病院における新来患者に関する調査
}

\author{
石田惠 ${ }^{11}$ 五十嵐公4) 押尾はるみ ${ }^{2)}$ 飯田 浩 司 ${ }^{2)}$ \\ 清 水 千 工 $^{2)}$ 俣 木 志 朗 ${ }^{3)}$ 黒 㟝 紀 正 ${ }^{2)}$ \\ 1) 東京医科歯科大学大学院医歯学総合研究科 全人的医療開発学系専攻 包括診療歯科学講座 口腔心身医学分野 \\ (主任：小野 繁教授) \\ 2)東京医科歯科大学大学院医歯学総合研究科 全人的医療開発学系専攻 包括䛦療歯科学講座 総合診療歯科学分野 \\ （主任：黑誩紀正教授） \\ ${ }^{3)}$ 東京医科歯科大学大学院医歯学総合研究科 全人的医療開発学系専攻 包括診療歯科学講座 柬科医療行動科学分野 \\ (主任：俣木志朗教授) \\ 4) 東京医科歯科大学大学院医歯学総合研究科 環境社会医歯学系専攻 医療政策学講座 医療経済学分野 \\ (主任：川㴊孝一教授) \\ (2000 年 12 月 8 日受付)
}

\section{A Survey of Awareness Among New Patients at the Department of Oral Diagnosis and General Dentistry}

\author{
Satoshi Ishida ${ }^{1)}$, Isao Igarashi ${ }^{4)}$, Harumi Oshio ${ }^{2)}$, Koji Iida ${ }^{2)}$ \\ Chie Shimizu ${ }^{2}$, Shiro Mataki ${ }^{3)}$ and Norimasa Kurosaki ${ }^{2)}$
}

1) Section of Oral and Maxillofacial Psychosomatic Medicine, Department of Comprehensive Oral Health Care,

Division of Comprehensive Patient Care, Graduate School, Tokyo Medical and Dental University

(Chief: Prof. Shigeru Ono)

2) Section of General Dentistry, Department of Comprehensive Oral Health Care,

Division of Comprehensive Patient Care, Graduate School, Tokyo Medical and Dental University

(Chief: Prof. Norimasa Kurosaki)

3) Section of Behavioral Dentistry, Department of Comprehensive Oral Health Care,

Division of Comprehensive Patient Care, Graduate School, Tokyo Medical and Dental University

(Chief: Prof. Shiro Mataki)

4) Section of Health Care Economics, Department of Health Science Policies, Division of Public Health, Graduate School, Tokyo Medical and Dental University

(Chief: Prof. Koichi Kawabuchi)

The purpose of this study is to know the outline of clinical statistics of new patients at the Clinic for Initial Diagnosis/Emergency, Dental Hospital, Tokyo Medical and Dental University. We examined 1,001 new patients who visited our hospital from 19 October to 8 December 1995.

The results were obtained as follows:

1. Our subjects were 1,001 patients, males were $357(35.7 \%)$ and females $644(64.3 \%)$. The ratio of male to female was $1: 1.8$.

2. Concering age distribution, the majorities were in their twenties and fifties in order.

3. $71.5 \%$ of patients said it took less than one hour for them to come to our hospital.

4. The rate of introduced patients was $5.5 \%$ of all the new patients. 


\section{I，緒言}

近年の我が国における社会構造の変化は，歯科医療界 にも少なから婛響を及ぼしており，歯科疾患構造なら びに患者の歯科治療に対する二ーズも大きく変化した。 これからの大学附属病院の在り方を検討する一助とする ため, 新来患者の概要を把握することを目的として臨床 統計的観察を行ったので報告する。

\section{II. 対象と方法}

1995 年 10 月 19 日（月）から 12 月 8 日（月）までに東 京医科㐘科大学菌学部附属病院総合診断部を受診した新 来患者 1,001 人を対象とした。

総合診断部は歯科総合診療部に改組されたが，本学附 属病院を受診する新来患者の最初の臨床部門で，問診と 簡単な診査を行い主訴に応じて尃門診療科（部）を紹介 している。本学附属病院では担当医があらかじめ決定し ている患者および口腔外科への紹介状持参患者，矯正科 または小児歯科の治療希望患者は直接各専門診療科を受 診することになっている。

今回, 新来患者の居住地と通院時間を調査し, 紹介状 を有した患者と有しない患者に分け，前者には紹介元の 医療機関と来院理由を，後者には本学を知った理由とそ の来院理由を多肢複数選択式のアンケート調査を行っ た。

\section{III. 結果と考察}

\section{1. 居住地と通院時間}

1) 居住地

1,001 名を東京その他の近県に分類したが, 東京の 673 名 (67.2\%) に次いで埼玉 148 名 (14.8\%)，千葉 84 名 (8.4\%), 神奈川 64 名 (6.4\%) の順で，ほとんどが東京
都とその近県からとなっていた（図1)。一方，北海道と 近畿地方がいずれも 4 名であったが，そのうち家族が東 京近辺に居住している者は治療を希望しており，そうで ない者は上京の機会に治療の相談を希望して来院してい た。これは歯科の大学附属病院としては国内において交 通の便に最も恵まれている1)ことが理由と考之られる。

2）通院時間

通院時間を 30 分単位の 5 段階に区切って調べた。31 分から 60 分が 495 名 (49.5\%) と最も多く，30 分以内が 221 名 $(22.1 \%)$, 次いで 61 分以上から 90 分以内が 173 名 (17.3\%) で，1 時間以内が 716 名 (71.5\%) と約 7 割 であったが, 2 時間を越えて来院する患者も $3.8 \%$ みられ た（図2）。

通院時間を調査したものは少ないが，広瀬ら ${ }^{2}$ は奥羽 大学病院では 30 分以内が $69.5 \%$ であり，一方，本学にお いては約 7 割では 1 時間以内となっていた。本学が交通 の便に恵まれているにもかかわらず，30 分も余分に通院 時間を要していることは，東京と地方の住宅事情の違い を反映していると思われる。

\section{2. 患者数と性別}

男女別では 1,001 名のうち男性 357 名（35.7\%）に対 して女性 644 名 (64.3\%) と, 男性に比較し女性が多く, 男女比は $1: 1.8$ であった。

性差にについては各施設から女性が多いとの報 告1,3 18)がなされている(表 1$)$ 。その男女比は $1: 1^{10)}$ から $1: 1.8$ (本報) と幅広いが，ほとんどの施設で 1 : $1.3^{3,6,9,11,13,15,16)}$ である。調査時間, 調查期間, 対象人数, 対象地域などを考慮すると病院を受診する患者は女性が 多いが，概して女性は就業率が低いなどの社会的な要因 に加之，一般的に男性よりも健康には関心が深いと考之 られる。

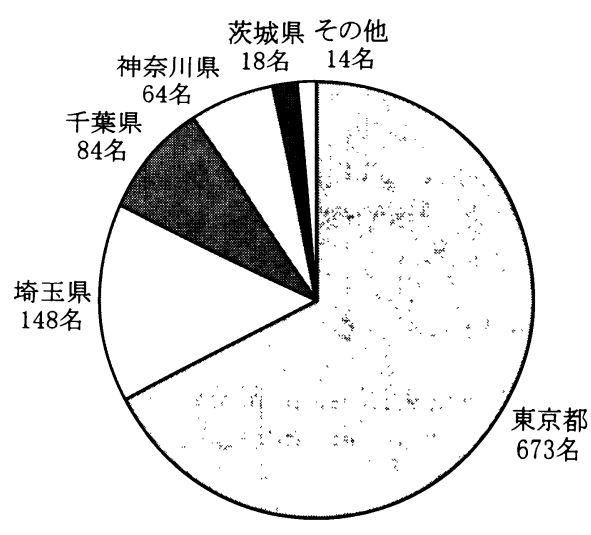

困 1 居住地（総数：1,001 名）

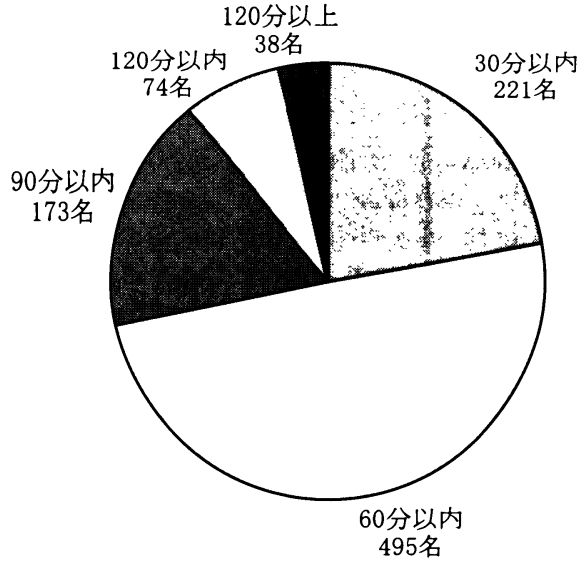

図 2 通院時間（総数：1,001 名） 
表 1 新来患者の男女比

\begin{tabular}{|c|c|c|c|c|c|}
\hline 報告者 & 報告年 & 場所 & 患者数 & 男女比 & 調査期間 \\
\hline 山崎美幸1) & 1985 & 本学 & 不明 & $1: 1.5$ & 不明 \\
\hline 奥村智信 ${ }^{3)}$ & 1986 & 日歯大 & 3,097 & $1: 1.3$ & 1 年 $(1984 \sim 1985)$ \\
\hline 奥村智信 ら ${ }^{4)}$ & 1994 & 日歯大 & 4,289 & $1: 1.4$ & 1 年 $(1992 \sim 1993)$ \\
\hline 伊藤雅章ら5) & 1996 & 日歯大 & 4,374 & $1: 1.5$ & 1 年（1994～1995） \\
\hline 小川光一ら ${ }^{6)}$ & 1988 & 岩手医大 & 2,158 & $1: 1.3$ & 1 年 $(1985)$ \\
\hline 大澤孝一ら & 1989 & 明海大 & 11,808 & $1: 1.2$ & 3 年 $\quad(1985 \sim 1987)$ \\
\hline 中野鼃一ら ${ }^{8)}$ & 1989 & 明海大 & 57,950 & $1: 1.1$ & 11 年 6 力月（1975. 6 1985. 12) \\
\hline 金子 淳ら ${ }^{9)}$ & 1989 & 東歯口外 & 7,627 & $1: 1.3$ & 4 年 $(1985 \sim 1988)$ \\
\hline 萩原良浩ら ${ }^{10)}$ & 1989 & 日大 & 642 & $1: 1$ & 1 年 $(1980)$ \\
\hline 小川光一ら ${ }^{11)}$ & 1989 & 岩手医大 & 6,300 & $1: 1.3$ & 3 年 $(1985 \sim 1987)$ \\
\hline 由井 悟ら ${ }^{12)}$ & 1993 & 東大 & 4,751 & $1: 1.1$ & 2 年 $(1990 １ 991)$ \\
\hline 小川光一ら ${ }^{13)}$ & 1994 & 岩手医大 & 5,339 & $1: 1.3$ & 1 年（1993） \\
\hline 富野照久ら ${ }^{14)}$ & 1997 & 明海大 & 29,859 & $1: 1.2$ & 6 年 7 力月（1986. 9 1992. 3） \\
\hline 戸塚盛雄ら ${ }^{15)}$ & 1997 & 岩手医大 & 21,339 & $1: 1.3$ & 4 年（1993～1996） \\
\hline 飯久保正弘 ら ${ }^{16)}$ & 1997 & 東北大 & 27,613 & $1: 1.3$ & 5 年（1990～1994） \\
\hline 藤沢盛一郎ら ${ }^{17)}$ & 1997 & 本学: & 54,665 & $1: 1.7$ & 4 年 $(1986 \sim 1987,1989 \sim 1990)$ \\
\hline 佐藤漛則ら ${ }^{18)}$ & 1999 & 防衛医大 & 1,788 & $1: 1.4$ & 1 年（1998） \\
\hline
\end{tabular}

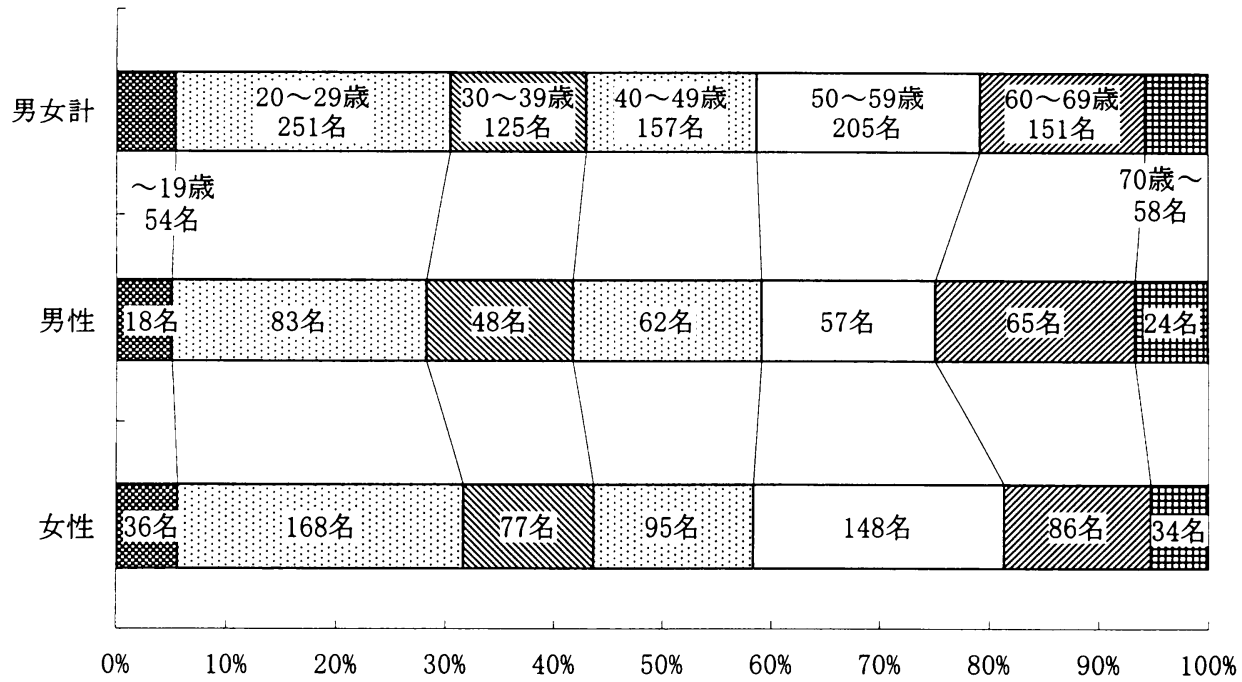

図 3 性別- 年齢別（男性：357 名, 女性：644 名, 総数：1,001 名）

\section{3. 年龄別分布}

20 歳代が 1,001 名のうち 251 名 (25.1\%) と一番多く, 次いで 50 歳代が 205 名 $(20.5 \%)$ であった。また， 20 歳 未満の 54 名と 70 歳以上の高齢者が 58 名とほぼ同数で あった（図 3 )。

年齢では各施設でまちまちで，東京歯科大学口腔外 科 ${ }^{9)}$ では 20 歳代が 1,758 名 $(23 \%)$ と多く，30 歳代が 1,454名 (19.1\%)，40 歳代が 1,280名（16.8\%）であっ たと報告し, 岩手医科大学歯学部でも 20 歳代が $21 \%$ 13) と最も多かったとし, 男女別に分析し, 男性では 10 歳未

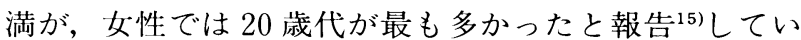
る。

その他の施設でも 20 歳代が最も多い ${ }^{4,12,16)}$ とてお $\eta$ ，調査年次にかかわらずに 20 歳代が多いのは，時間的 にも通院する多少の余裕があることが考えられるが，女 性と同様この年代の者は歯科治療および口腔衛生には関 心が深いと考えられた。20 歳未満が少ないのは総合診断 部では小児歯科，矯正科の受診を希望する患者は原則と

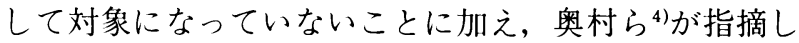
ているように初診受付が午前中であり，通学時間，授業 


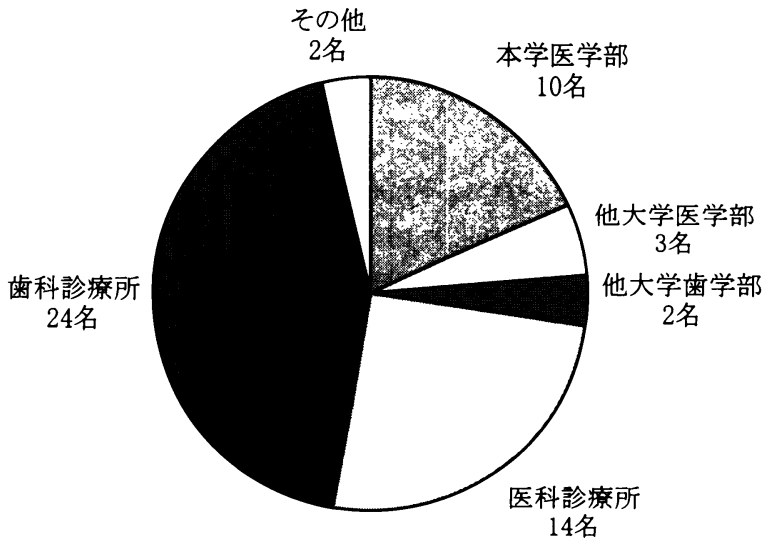

困 4-1 紹介元医療機関（対象：55名）

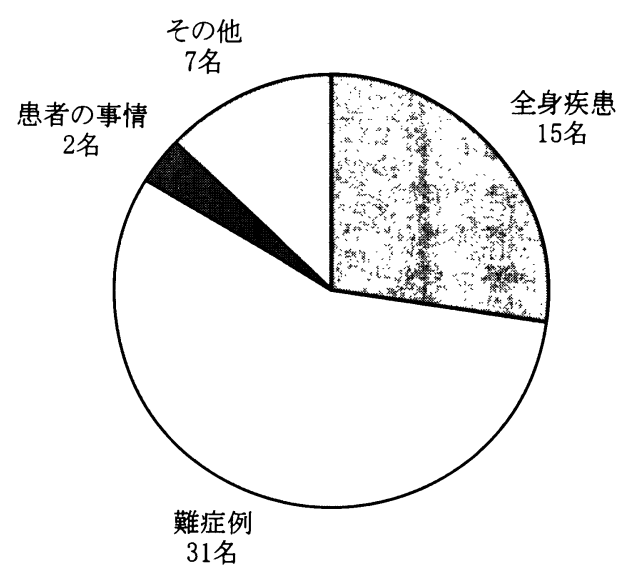

図 4-2 紹介理由（対象：55 名）
時間と重なるためと考えられる。この背景には交通事故 などの外傷に伴う歯科疾患や急性炎症などは救急歯科医 療を歯科大学が担うことが少なく，対象とする歯科疾患 がほとんど慢性疾患が占めているものと考えられた。

\section{4. 紹介元医療機関と紹介理由}

紹介状を有した患者は 55 名（5.5\%）で，紹介状を有 しない新来患者 946 名 $(94.5 \%)$ に対して非常に少なかっ た。

紹介状を有する患者は由井ら ${ }^{12)}$ は東京大学口腔外科 では 4,751 名中 1,578名 $(33.2 \%)$ ，広瀬ら ${ }^{2)}$ は $49.2 \%$ ， 小川ら ${ }^{13)}$ は $35.3 \%$, 富野ら ${ }^{14)}$ は $46.5 \%$ と報告している。 また, 小川ら ${ }^{19)}$ は一般歯科の紹介患者の割合は昭和 50 年 の $17.1 \%$ から徐々に増加し, 昭和 58 年には $40.7 \%$ まで になり，専門科への紹介率が上がってきていると報告し た。

これらに比べ，総合診断部への紹介率が非常に少ない が,これは総合診断部では治療を主として行っておらず, 本学では専門診療科（部）への紹介状を有する患者は直 接専門診療科 (部) に行くことになっていたからである。

なお，1999 年には総合診断部は総合治療部になってい る。

紹介元の医療機関は本学医学部, 他大学医学部, 他大 学歯学部, 医科診療所, 歯科診療所, その他の 6 項目に 分類した。歯科診療所, 次いで医科診療所, 本学医学部 の順に多かった（困 4-1）。

東京大学口腔外科では東京大学病院内の他診療科から が $24.2 \%$ を占め, 他病院歯科（歯科診療所と思われ る）が 4,751 名中 199 名 (4.2\%) であり，総計 $33.2 \%$ の紹介患者のうち, 本院内の $24.2 \%$ の他の診療科の内訳 では内科系が多いと報じている。この理由として口腔粘 膜疾患や舌痛症などで内科を受診する者や内科での入院 や通院期間が比較的長い患者は内科治療中に歯科受診を
する機会が多いためと考えている20)。このように医学部 附属病院内にある歯科口腔外科は一般歯科的疾患が初診 の約 50\%であり, 紹介患者の $66.5 \%$ が一般歯科的疾患の 患者で，歯科口腔外科というより歯科と考えられている と指摘している。岩手医科大学歯学部附属病院では紹介 元は自大学医学部が $1 / 4$, 学外の歯科が $2 / 3$ で最も多く, そのほとんどが歯科医院であり ${ }^{13)}$, 東北歯科大学 (奥羽大 学歯学部) では開業医（診療所）の紹介は $9.1 \%$ であり， 大学が開業医の指導的立場にあることを指摘してい る $^{12)}$ 。

総合診断部の場合に歯科診療所から多く紹介されてい ることは特徴としてとらえることができる。

またその紹介理由については，(1)全身疾患を有してい る患者，(2)難症例とされる治療が難しい患者，(3)患者の 事情によるもの, (4)その他の 4 項目に分類を行った。

歯科診療所と医科診療所の紹介理由はともに歯科的な 難症例が多く，それぞれ 83.3\%, 57.1\%を占めていたが, 本学医学部からの紹介は患者のほとんどが全身疾患を有 していた（図 4-2）。

\section{5. 紹介状を有しない患者の来院動機の情報源}

当医院を知るに至った情報源としては友人・知人，家 族，各種メディア，歯科医師の指示，医師の指示，その 他（以前から知っていたなど）の 6 項目に分類した。延 べ 1,059 名のうち(複数回答可)，情報源としては多い順 に友人・知人が $31.6 \%$ ，家族が $25.8 \%$ ，その他が $23.0 \%$ の順であった（図 5)。

来院動機の情報源ではいわゆる「口コミ」によるもの が大部分を占めていたと考えられたが，広瀬ら ${ }^{2)}$ 知人 の紹介が $33.5 \%$ と最も多く, 次いで病院職員の紹介が $6.6 \%$ であったと同様の見解を述べている。

男女別にみると男性は女性に比べて歯科医師の指示や その他の割合が多く，女性は男性に比べて友人・知人， 


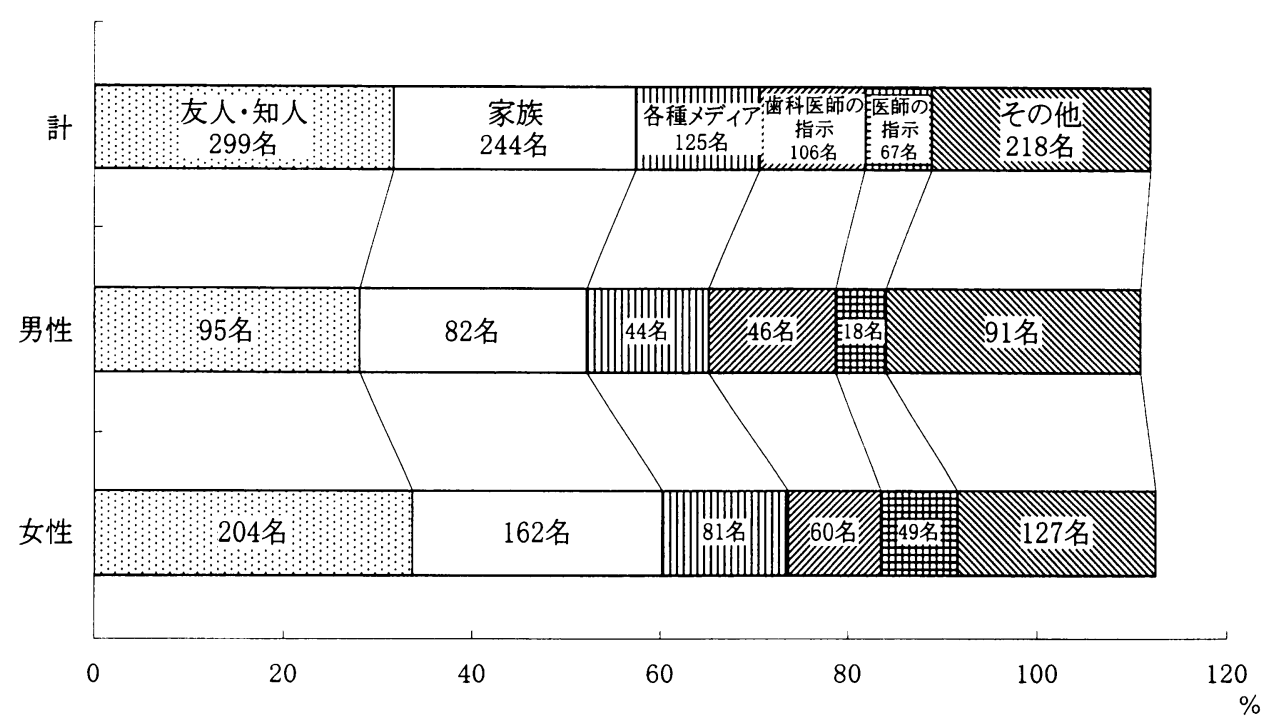

困 5 情報源（男性：339 名，女性：607 名，計：946 名） (複数回答可)

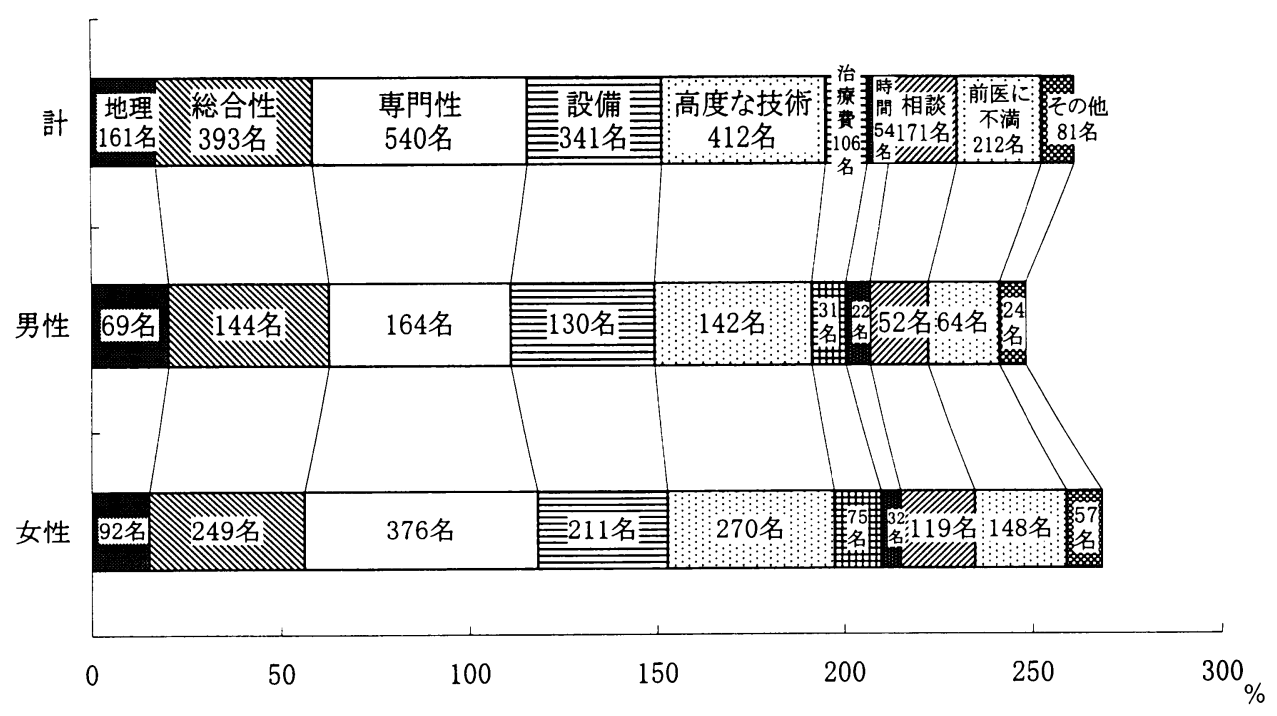

困 6 来院の動機（男性：339名, 女性：607名, 計：946名) (複数回答可)

家族の割合が多かった。受診に対する積極的な姿勢は女 性に強くみられた。女性はこの面でも大病院志向あるい は良質で高度な医療を求めていると考えられた。

\section{6. 来院の動機}

地理的条件, 総合性, 専門性, 設備の充実, 高度な技 術, 治療費, 時間的余裕, 治療の相談, 前医への不満, その他の 10 項目に分類した。

男女別にみると男性は女性と比べて地理的条件の割合 が多く，女性は男性に比べて専門性や前医への不満，治 療の相談などが多かった(図 6)。ここでも女性が概して，
より積極的に情報を集め，良質の医療を期待する傾向が あると考えられた。

設問が異なるが小澤ら ${ }^{21)}$ は大学なら安心であるとの初 診患者のアンケートを報告している。いずれにしても大 学は総合性, 専門性, 高度な技術, 設備の充実を期待さ れていることが再認識された。

成人の医療受療態度についての調査 ${ }^{22,23)}$ によば，女 性がより積極的であると報告している。奥村ら ${ }^{4}$ はマス メディアの影響から口臭，咬み合わせ，顎関節の異常， 院内感染などの症状を訴える患者が多く来院していた 
が,女性が積極的であったと報告した。斎藤ら ${ }^{24}$ (は歯科治 療を受けるのが怖いという意識を全体の約 $65 \%$ の者が 持ち，男性が $44.3 \%$ であるのに対して，女性が $74.9 \%$ と 女性にその傾向が強いとしていたが，この意識を超えて 歯科医療受診率が女性に高いことは特筆するに值する。

大学病院に対するイメージとして広瀬ら ${ }^{2}$ は理想的な 治療をすると考える人が $32.7 \%$ と最も多く，次いで誰で も治療を受けられるが $22.4 \%$ と病院の公共性を挙げて いる。これに次いで普通の歯科医院と変わらないが, $13.1 \%$ との見方がある一方，学生の臨床実習を行ってい ないにもかかわらず学生の教材にされるが $9.6 \%$, 実験 材料にされるが $8.5 \%$ な゙の結果も得られ，大学病院の 診療システムがよく知られていない面もあると指摘して いる。この点では本学は現在も学生の臨床実習を行って いるので，大学による差とも考えられる。

\section{IV. 結 語}

本調査以降インプラント治療部，顎関節治㙩部，心身 症外来が整備されたが，患者の二ーズに応之，大学病院 としての良質で高度の医療を提供し，その機能を十分に 発揮できるよう，さらに幅広い調査と分析が望まれると 思われた。

なお本論文の要旨は, 平成 8 年 5 月 18 日の第 9 回日本 口腔診断学会総会（盛岡）において発表した。

\section{文献}

1）山崎美幸：歯学部附属病院を訪れる新来患者の実態につ いて。デンタルハイジーン 5(8): 813-816, 1985.

2）広瀬 秀, 寺田 誠, 渡貫 健, 他：東京大学附属病院開 設 1 年目における外来患者の実態調查 (第 1 報)。東北歯 大誌 $1(1) ： 41-49,1974$

3）奥村智信：日本歯科大学附属病院外来患者の動勢につい て. 歯学 $74: 232-233,1986$.

4）奥村智信，落合 均，住友雅人，他：日本歯科大学附属病 院外来患者の動勢についてーその 2-。㐘学 81 (5)： 1256-1262，1994

5）伊藤雅章, 高橋建作, 佐藤洋作, 他：日本歯科大学附属属 病院初診外来患者の動勢について。目歯保存誌 $39(2)$ : 536-541, 1996.

6）小川光一，户塚盛雄：多変量解析による料科疾患の部位 情報の要約。日口診誌 $1(1): 68-76,1988$ 。

7）大澤孝一，柴田秀美，增田 屯，他：本学予診科における 過去 3 年間の新患の全身的既往歴の調査。日口診誌 2 (1) : 143-152,1989.
8）中野憲一, 岡田典久, 増田 屯, 他：明海大学㐘学部子診 科における過去 16 年間の新患の臨床統計的観察. 明海歯 学誌 $18(3) ： 382-389,1989$

9）金子 淳, 小沢靖弘, 畑田憲一,他：当教室における最近 4 年間の患者統計。（抄）日口診誌 $2(2) ： 57,1989$.

10）萩原良浩, 田代明子, 松浦信人, 他：日本大学歯科病院口 腔診断科来院患者について<年内変動からの解析＞(抄) 日口診誌 $2(1) ： 257,1989$.

11）小川光一,福田容子, 户塚盛雄：疾患別に集計した現病歴 のデーター解析. (1) データーの要約について (抄) 日口 診誌 $1(1)$ : 256, 1989 .

12）由井 悟，古森孝英，伊東大典，他：最近 2 年間の当科 受診患者における臨床統計的検討。日口診誌 $6(1)$ ： 12-16, 1993

13）小川光一，戸塚盛雄：岩手医科大学歯学部附属病院受診 患者の来院経路について。日口診誌 7(2)：449-450, 1994 .

14）富野照久, 麻生幸男, 三村 里, 他：明海大学附属病院口 腔診断科における新患の臨床統計的観察。日口診誌 10 (2) : 494-495, 1997.

15）戸塚盛雄，小川光一：岩手医科大学歯学部附属病院にお ける最近 4 年間の初診患者の臨床統計的観察 (抄)。日口 診誌 $10(2) ： 495 ， 1997$.

16）飯久保正弘, 笹野高嗣, 栗原直之, 他：口腔粘膜疾患の臨 床統計一第 3 報 過去 5 年間の当院新来患者につい て一。目口診誌 $10(1) ： 46-52 ， 1997$

17）藤沢盛一郎，山本 仁，山本あかね，他：総合彰断部にお ける 4 年間の新来患者の臨床統計的観察。口病誌 64 (2) : 376-383, 1997

18）佐藤漛則，宮下直也，君島 裕，他：当科外来新来患者に おける有病者の臨床統計的観察。一平成 10 年 1 月より同 年 12 月までの 1 年間一。日口診誌 12 (2)：404-410, 1999

19）小川光一, 石井由美子, 戸塚盛雄, 他：岩手医科大学歯学: 部附属病院に㧈ける最近 9 年間の新来患者の臨床統計的 観察。岩医大㐘誌 $10 ： 149-160 ， 1985$

20）古森孝英，高戸 毅，横山恵以子，他：歯科口腔外科にお ける院内紹介患者の臨床統計的観察。口病誌 61 (2)： 237-242, 1994

21）小澤義彦, 小林 力, 佐藤光洋, 他：日本歯科大学附属病 院に打ける初診患者の意識調査。歯学 76(3)： $524-525,1988$.

22）八重垣 健，末高武彦，榎本美佳子，他：医燎受燎態度に 関する調査. 歯学 75(4)：680-681,1987.

23）榎本美佳子，末高武彦，金沢紀子，他：産業従事者の医療 受療態度に関する調査研究. 口腔衛生会誌 36 ： $378-379,1986$

24）斎藤孝親，多田充裕博，須永 亨, 他：初診患者の実態に 関する研究. 第 2 報：患者の医療に対する意識について。 日口診誌 $3(1)$ : 61-67, 1990 . 